at $\mathrm{BL}$ and $\mathrm{Wk} 104 ;^{2}$ association between decrease/increase in erosion score on $\mathrm{MRI}$ and decrease/increase in erosion or sacroiliitis grade on radiographs, BL to Wk 104.

Methods: All patients had early axSpA. EMBARK: 12 wks double-blind placebocontrol, then 92 wks open-label etanercept. DESIR: patients had no history of biologics and received no biologics for 104 wks. MRI images from both studies: combined, anonymized, and read per patient; radiographs combined, anonymized, read separately from MRI. Readers unaware of: image chronology, original cohort. Three experienced readers individually reviewed T1 weighted MRI using SpondyloArthritis Research Consortium of Canada SIJ Structural Score; 3 different readers assessed radiographic sacroiliitis using $\mathrm{mNY}$ grade; all were at level of each joint surface. Lesion presence/absence or decrease/increase recorded per patient if $\geq 2$ of 3 readers agreed. Statistical analyses: $\kappa$ coefficient of agreement, McNemar's test for discordance asymmetry.

Results: 224 patients had MRI and radiographs. At BL, concordance for presence or absence of erosion in 162/224 (72.3\%) ( $\kappa=0.42)$, table 1. Discordance: erosion more frequent on MRI $(21.4 \%)$ than radiographs $(6.3 \% ; p<0.0001)$. Wk 104 data similar to BL. Decrease in erosion more frequent than increase only on $\mathrm{MRI}$; significantly more frequent on MRI than radiographs. Decrease in erosion on $\mathrm{MRI}$ significantly more frequent than decrease in sacroiliitis grade.

Abstract FRI0216 - Table 1. Concordance between MRI and Radiographs, BL and Wk 104; and Change BL to Wk 104

\begin{tabular}{|c|c|c|c|c|c|c|c|}
\hline & $\mathrm{N}$ & $\begin{array}{c}\text { Present/ } \\
\text { Present } \\
\mathrm{n}(\%)\end{array}$ & $\begin{array}{c}\text { Absent/ } \\
\text { Absent } \\
\mathrm{n}(\%)\end{array}$ & $\begin{array}{c}\text { Absent/ } \\
\text { Present } \\
\mathrm{n}(\%)\end{array}$ & $\begin{array}{c}\text { Present/ } \\
\text { Absent } \\
\mathrm{n}(\%)\end{array}$ & $\begin{array}{c}\kappa \\
(95 \% \mathrm{Cl})\end{array}$ & P-value* \\
\hline $\begin{array}{l}\text { BL Erosion: MRI/ } \\
\text { radiographs }\end{array}$ & 224 & $\begin{array}{c}50 \\
(22.3)\end{array}$ & $\begin{array}{c}112 \\
(50.0)\end{array}$ & $\begin{array}{c}14 \\
(6.3)\end{array}$ & $\begin{array}{c}48 \\
(21.4)\end{array}$ & $\begin{array}{c}0.42 \\
(0.30- \\
0.53)\end{array}$ & $<0.0001$ \\
\hline $\begin{array}{l}\text { Wk } 104 \text { Erosion: MRI/ } \\
\text { radiographs }\end{array}$ & 222 & $\begin{array}{c}44 \\
(19.8)\end{array}$ & $\begin{array}{c}119 \\
(53.6)\end{array}$ & $\begin{array}{c}15 \\
(6.8)\end{array}$ & $\begin{array}{c}44 \\
(19.8)\end{array}$ & $\begin{array}{c}0.41 \\
(0.29- \\
0.53)\end{array}$ & 0.0002 \\
\hline $\begin{array}{l}\mathrm{BL} \text { : Erosion on MRI/ } \\
\text { sacroiliitis on } \\
\text { radiographs }\end{array}$ & 224 & $\begin{array}{c}60 \\
(26.8)\end{array}$ & $\begin{array}{c}97 \\
(43.3)\end{array}$ & $\begin{array}{c}29 \\
(12.9)\end{array}$ & $\begin{array}{c}38 \\
(17.0)\end{array}$ & $\begin{array}{c}0.39 \\
(0.26- \\
0.51)\end{array}$ & 0.27 \\
\hline $\begin{array}{l}\text { Wk 104: Erosion on } \\
\text { MRI/sacroiliitis on } \\
\text { radiographs }\end{array}$ & 222 & $\begin{array}{c}56 \\
(25.2)\end{array}$ & $\begin{array}{c}99 \\
(44.6)\end{array}$ & $\begin{array}{c}35 \\
(15.8)\end{array}$ & $\begin{array}{c}32 \\
(14.4)\end{array}$ & $\begin{array}{c}0.37 \\
(0.25- \\
0.50)\end{array}$ & 0.71 \\
\hline $\begin{array}{l}\text { Erosion decrease: } \\
\text { MRI/radiographs }\end{array}$ & 221 & $4(1.8)$ & $\begin{array}{c}162 \\
(73.3)\end{array}$ & $6(2.7)$ & $\begin{array}{c}49 \\
(22.2)\end{array}$ & $\begin{array}{c}0.06 \\
(-0.05 \\
0.16)\end{array}$ & $<0.0001$ \\
\hline $\begin{array}{l}\text { Erosion increase: } \\
\text { MRI/radiographs }\end{array}$ & 221 & $2(0.9)$ & $\begin{array}{c}187 \\
(84.6)\end{array}$ & $\begin{array}{c}17 \\
(7.7)\end{array}$ & $15(6.8)$ & $\begin{array}{c}0.03 \\
(-0.12 \\
0.18)\end{array}$ & 0.72 \\
\hline $\begin{array}{l}\text { Erosion decrease on } \\
\mathrm{MRI} / \text { sacroiliitis grade } \\
\text { decrease on } \\
\text { radiographs }\end{array}$ & 221 & $8(3.6)$ & $\begin{array}{c}154 \\
(69.7)\end{array}$ & $\begin{array}{c}14 \\
(6.3)\end{array}$ & $\begin{array}{c}45 \\
(20.4)\end{array}$ & $\begin{array}{c}0.08 \\
(-0.05 \\
0.21)\end{array}$ & $<0.0001$ \\
\hline $\begin{array}{l}\text { Erosion increase on } \\
\mathrm{MRI} / \text { sacroilitis grade } \\
\text { increase on } \\
\text { radiographs }\end{array}$ & 221 & $4(1.8)$ & $\begin{array}{c}180 \\
(81.4)\end{array}$ & $\begin{array}{c}24 \\
(10.9)\end{array}$ & $13(5.9)$ & $\begin{array}{c}0.09 \\
(-0.07 \\
0.25)\end{array}$ & 0.07 \\
\hline
\end{tabular}

*McNemar's test for discordance asymmetry.

$\mathrm{BL}$, baseline; Wk, Week.

Conclusions: Findings of SIJ structural damage are observed differently on radiography and $\mathrm{MRI}$ in patients with early axSpA, and may appear to evolve differently.

Disclosure of Interest: W. Maksymowych Grant/research support from: AbbVie, Pfizer, Consultant for: Abbvie, Janssen, Lilly, Merck, Novartis, Pfizer, UCB, P. Claudepierre Consultant for: Abbvie, BMS, Celgene, Janssen, Novartis, Merck, Pfizer, Roche, UCB, Lilly, M. de Hooge Employee of: Selfemployed without other personnel (registered company under the Belgium law) MdH Research. Additional Affiliation: Ghent University, Ghent, Belgium, R. Lambert Consultant for: AbbVie, Bioclinica, Janssen, Parexel, UCB, R. Landewé Grant/research support from: Abbott, Amgen, Centocor, Novartis, Pfizer, Roche, Schering-Plough, UCB, Consultant for: AbbVie, Ablynx, Amgen, Astra-Zeneca, Bristol Myers Squibb, Celgene, Janssen, Galapagos, GlaxoSmithKline, Novartis, Novo-Nordisk, Merck, Pfizer, Roche, Schering-Plough, TiGenix, UCB, Employee of: Director of Rheumatology Consultancy BV, which is a registered company under Dutch law, Speakers bureau: Abbott/AbbVie, Amgen, Bristol Myers Squibb, Janssen, Merck, Pfizer, Roche, Schering-Plough, UCB, A. Molto Grant/research support from: Pfizer, Consultant for: Merck, UCB, D. van der Heijde Consultant for: AbbVie, Amgen, Astellas, AstraZeneca, BMS, Boehringer Ingelheim, Celgene, Daiichi, Lilly, Galapagos, Gilead, GlaxoSmithKline, Janssen, Merck, Novartis, Pfizer, Regeneron, Roche, Sanofi, Takeda, UCB, Employee of: Director of Imaging Rheumatology bv, J. Bukowski Shareholder of: Pfizer, Employee of: Pfizer, H. Jones Shareholder of: Pfizer, Employee of: Pfizer, I. Logeart Shareholder of: Pfizer, Employee of: Pfizer, L. Marshall Shareholder of: Pfizer, Employee of: Pfizer, R. Pedersen Shareholder of: Pfizer, Employee of: Pfizer, A. Szumski
Employee of: InVentiv Health, B. Vlahos Shareholder of: Pfizer, Employee of: Pfizer, M. Dougados Grant/research support from: Pfizer, AbbVie, UCB, Merck and Lilly, Consultant for: Pfizer, AbbVie, UCB, Merck and Lilly DOI: 10.1136/annrheumdis-2018-eular.2124

\section{FRI0217 DIAGNOSTIC ASCERTAINMENT OF AXIAL SPONDYLOARTHRITIS IN PATIENTS PRESENTING WITH UNDIAGNOSED BACK PAIN: WHAT IS THE IMPACT OF MRI IN RHEUMATOLOGICAL PRACTICE?}

R.G. Lambert ${ }^{1}$, R. Carmona ${ }^{2}$, J. Yeung ${ }^{3}$, J. Chan ${ }^{4}$, L. Martin ${ }^{5}$, S. Aydin ${ }^{6}$, D. Mosher ${ }^{5}$, A. Masetto ${ }^{7}$, S. Keeling ${ }^{8}$, O. Ziouzina ${ }^{5}$, S. Rohekar', J. Paschke ${ }^{10}$ A. Carapellucci ${ }^{10}$, W.P. Maksymowych ${ }^{8,10}$. ${ }^{1}$ Radiology, University of Alberta, Edmonton; ${ }^{2}$ St. Joseph's Healthcare Hamilton, Hamilton; ${ }^{3}$ James Yeung Rheumatology, Richmond; ${ }^{4}$ Artus Health Clinic, Vancouver, ${ }^{5}$ University of Calgary, Calgary; ${ }^{6}$ Ottawa Hospital, Ottawa; ${ }^{7}$ Université de Sherbrooke, Sherbrooke; ${ }^{8}$ Medicine, University of Alberta, Edmonton; ${ }^{9}$ Lawson Health Research Institute, London; ${ }^{10}$ CaRE Arthritis Ltd., Edmonton, Canada

Background: In current rheumatology practice, the circumstances that prompt clinicians to order MRI in patients with suspected axSpA are unclear. In addition, the manner and degree to which MRI changes diagnostic ascertainment of axSpA in patients presenting with undiagnosed back pain has not been formally studied. Objectives: 1. To determine whether any particular patient demographic and/or disease characteristics are associated with rheumatologist ordering of MRI. 2. To assess the impact of MRI evaluation on diagnostic ascertainment of axial SpA in patients presenting with undiagnosed back pain.

Methods: The multicenter Screening for AxSpA in Psoriasis, Iritis, and Colitis (SASPIC) Study is aimed at early detection of axial SpA in consecutive patients presenting with undiagnosed back pain to the rheumatologist. Consecutive patients with any one of psoriasis, iritis, or colitis diagnosed by the relevant specialist undergo routine evaluation by a rheumatologist. The rheumatologist determines the presence/absence of axial SpA and the degree of confidence in the diagnosis ( -10 (definitely not SpA) to +10 (definite $\mathrm{SpA}$ ) on a NRS) at 3 consecu tive stages: 1. After the clinical evaluation; 2. After the results of labs (B27, CRP) and radiography; 3 . After the results of MRI. Differences in patient demographics and/or disease characteristics between those who did or did not have MRI were assessed by chi-square and t-tests. We assessed the degree of diagnostic reclassification after each step at the categorical level (axial SpA yes/no) and also according to the degree of confidence.

Results: 244 patients $(51.6 \%$ male, mean age 34.6 years, mean age at symptom onset 27.4 years, mean back pain duration 7.1 years, $B 27+37.2 \%$ ) were referred with AAU (29.9\%), psoriasis (21.7\%), Crohn's colitis $(32.8 \%)$, ulcerative colitis (19.3\%). A diagnosis of axSpA was made in $67.5 \%$ after stage 1 clinical evaluation and in $56.4 \%$ at stage 2 after review of the labs and radiography. MRI evaluation varied across sites (mean(range): $73 \%(16.7 \%>100 \%)$ of patients), ordered in 141 patients, and significantly more frequently in those with probable inflammatory type back pain (probability $>5(0-10$ scale) $(p=0.04)$, when radiography was $m N Y-(p=0.005)$ and in those without Crohn's colitis $(p=0.001)$. No differences in ordering of MRI were noted according to age, gender, disease duration, back pain severity, NSAID response, B27 status, or CRP level. In patients with completed $\mathrm{MRI}$ scans, a diagnosis of axSpA was made in $70.5 \%$ after stage 1 clinical evaluation, in $56.4 \%$ after review of the labs and radiography, and in $47.3 \%$ after MRI review. 24 (18.6\%) were recategorized from SpA to non-SpA and 4 (3.1\%) from non-SpA to SpA. Confidence in diagnostic categorization was increased after MRI.

\begin{tabular}{|c|c|c|c|c|}
\hline $\begin{array}{c}\text { Stage of } \\
\text { Assessment }\end{array}$ & $\begin{array}{c}\text { axSpA present } \\
\text { n (\%) }\end{array}$ & $\begin{array}{l}\text { Mean (SD) } \\
\text { confidence }\end{array}$ & $\begin{array}{c}\text { axSpA absent } \\
\text { n (\%) }\end{array}$ & $\begin{array}{l}\text { Mean (SD) } \\
\text { confidence }\end{array}$ \\
\hline 1. Clinical only & $\mathrm{n}=91(70.5)$ & $5.5(2.4)$ & $n=38(29.5)$ & $3.4(3.2)$ \\
\hline $\begin{array}{l}\text { 2. Clinical plus } \\
\text { labs and } \\
\text { radiography }\end{array}$ & $\mathrm{n}=81(62.8)$ & $5.9(2.9)$ & $\mathrm{n}=48(37.2)$ & $5.1(3.6)$ \\
\hline $\begin{array}{l}\text { 3. Clinical, labs, } \\
\text { radiography, plus } \\
\text { MRI }\end{array}$ & $\mathrm{n}=61(47.3)$ & $7.5(2.9)$ & $\mathrm{n}=68(52.7)$ & $7.5(2.5)$ \\
\hline
\end{tabular}

Conclusions: In a setting of undiagnosed back pain and higher risk for axial SpA, use of MRI is primarily driven by negative radiography. MRI was primarily helpful in ruling out SpA and reducing false positives.

Disclosure of Interest: None declared

DOI: 10.1136/annrheumdis-2018-eular.4841 